\title{
Prospect of Deoiled Jatropha curcas Seedcake as Fertilizer for Vegetables Crops - A Case Study
}

\author{
Penjit Srinophakun (Corresponding author) \\ Department of Chemical Engineering, Faculty of Engineering, Kasetsart University \\ 50 Ngamwongwan Road, Chatuchak, Bangkok 10900, Thailand \\ Tel: 66-2-942-8555 E-mail: fengpjs@ku.ac.th
}

Boosaree Titapiwatanakun

KU-biodiesel project and Center Of Excellence for Jatropha, Kasetsart University, Thailand

Isara Sooksathan

Department of Agronomy, Faculty of Agriculture, Kasetsart University, Thailand

Vittaya Punsuvon

Department of Chemistry, Faculty of Science, Kasetsart University, Thailand

Received: August 18, 2011

Accepted: September 6, $2011 \quad$ Online Published: December 29, 2011

doi:10.5539/jas.v4n3p211

URL: http://dx.doi.org/10.5539/jas.v4n3p211

\begin{abstract}
The biodiesel from Jatropha curcas had been received much attention in these past decades. The seed was accountable for its high oil content. Through the development of oil expeller machine, the remains of an oil extraction were subjected to this study in order to examine the potential of deoiled Jatropha curcas seedcake (JSC) for being used as an organic fertilizer. However, the main concern was the presence of a toxic compound named phorbol ester in the JSC. The bio-safety questions were often regarded as the main concerns for the utilization of JSC as fertilizer. Therefore, the Chinese kale, tomato, and sweet potato were chosen to represent as the leaf, fruit, and tuber vegetable, respectively, which were subjected to the application of JSC as fertilizer. Here, the aspects of plant growth, yield, nutrient, and amount of phorbol ester in such plant parts as well as in the soil were analyzed. Although the treatments in each crops were practically the same, the specified details namely an exact rate of chemically fertilizer were slightly varied. The effects of half rate of chemical fertilizer mixed with high rate of JSC as fertilizer on the yields of Chinese kale and tomato were proven to be on the increase. This same treatment had mostly affected the growth characteristics of sweet potato. The total percentages of nitrogen $(\mathrm{N})$, phosphorous $(\mathrm{P})$, and potassium $(\mathrm{K})$ in the vegetable products were subsequently inspected. Not only the qualities of pre-planting soil, in terms of $\mathrm{pH}$, organic matter, and available $\mathrm{P}$ and $\mathrm{K}$ were analyzed, but also that of postharvest. Analytical measurements of phorbol ester via both HPLC and LC-MS/MS, were performed in all the samples from both harvested plant parts as well as soil. From all the postharvest propagations, the toxicity of phorbol ester could not be found, neither from the plant products nor the soil. Therefore, utilization of JCS as organic fertilizer for vegetable crops was marked as a safe practice, both for the consumer consumption and soil environment. This outcome can be of choice to solve the problem of rising fertilizer prices.
\end{abstract}

Keywords: Deoiled Jatropha curcas seed cake, Fertilizer, Phorbol ester, Vegetable crops

\section{Introduction}

\subsection{Seedcake of Jatropha curcas}

Jatropha curcas serves as a good source of alternative energy, since it produces the seed oils that can be used as a biodiesel. The high oil contents resided in Jatropha seed made it applicable for scientists to research for this biodiesel aspect (reviewed in Juan et al., 2011; Koh and Ghazi, 2011; Jain and Sharma, 2010). The oil extraction 
from Jatropha seed resulted in a massive amount of the seedcake. In practicality, 4 kilograms of fresh Jatropha seeds can yield only 1 kilogram of Jatropha oils. Therefore, this creates a large amount of solid waste left after an oil extraction. The deoiled Jatropha curcas seedcake, hereafter referred as JSC, contained up to $58 \%$ of crude protein by weight (Achten et al., 2008). The percentages of nitrogen $(\mathrm{N})$, phosphorous $(\mathrm{P})$, and potassium (K) were $3.2-4.5 \%, 1.4-2.1 \%$, and $1.2-1.7 \%$, respectively (Kumar and Sharma, 2008). The presences of these elements were recognized as the organic nutrients sources that are even higher than that of chicken or cow manure (Achten et al., 2008). Moreover, JSC still contained the compositions of primary and secondary elements required for plant growth.

\subsection{Usages of fertilizeres}

Due to the fact that Thailand is an agricultural country, a lot of Thai farmers cultivate their agricultural products in many areas. The yielding of products can be accelerated by the usage of fertilizers (Sands et al., 2009). In normal practice, the applications of chemical fertilizer, especially with the high rate of $\mathrm{N}$, required for the vegetable production. For example, the different levels of fertilizer (various amount of N, P, and K) had greatly affected the vegetative characteristics and yield of tomato crop (Al-Mohammadi and Al-Zu'bi, 2011). The authors showed that both the soil chemical properties and the nutrient content in tomato plant were influenced by the addition of fertilizer. Moreover, as an organic substrate could enhance the soil properties, Jouquet et al. (2011) had reported the evidence of utilization of vermicompost as fertilizer to improve plant growth. This study, therefore, evaluated the potential of using JSC as a source of organic nutrient to further nurture the growth of vegetable crops. More than a decade ago, it had been reported that there was a usage of JSC as fertilizer for growing potatoes (Gubitz et al., 1999). There were shown that crops of pearl millet, cabbage, and rice had high percent of yield increases after an application of JSC as fertilizer comparing to none application (Achten et al., 2008).

\subsection{Toxic compound in Jatropha curcas}

However, Jatropha curcas contains the element named phorbol ester (phorbol-12-myristate 13-acetate), which is considered to be toxic to human and animal consumption. The toxicity of phorbol ester is ranged from skin irritation to a production of tumor (Goel et al., 2007). Thus, whether the utilization of JSC is applicable for fertilizer usages remains questionable. The cautious utilization of JSC must be consequently adopted. Although there were reports of utilization of JSC as fertilizer (Kumar and Sharma, 2008), data regarding its amount of phorbol ester was still missing. Although the detoxification of JSC had been reviewed, JSC was detoxified by four repetitions of ethanol extraction (Saetae and Suntornsuk, 2011), which could be a laborious task. The objective of this study is to, therefore, determine the residue of phorbol ester retained both in the edible parts of vegetable and the soil that had been applied JSC as organic fertilizer for crop productions.

\subsection{Experimental approaches}

Chinese kale, tomato and sweet potato were selected and planted as the leafy vegetable, fruit vegetable and tuber vegetable test crops, respectively. Edible parts of all crops were harvested for yield data and analyzed for phorbol ester content. Soil sampling after harvesting each crop were analyzed for phorbol ester residue as well. In particular, the harvests of tomato were divided into three different time points, in order to inspect the various concentration of phorbol ester as the tomato fruits developed. The outcome of this research also aided the agricultural community to develop the practical utilization of JSC. Although the composting method of bio-waste could result in a fertilizer as well, the decomposition of bio-waste still needed a verification of desirable compost (van Wyk, 2001). This study, therefore, provided the evidences for such verifications.

\section{Materials and methods}

\subsection{Farm site}

All of the vegetables crops were grown in the area of Ayutthaya province. The plantation of vegetable crops was situated in the area of research farm within Suwannapoom Rajmongkol University at Ayuttaya Province. This area was located in the central plain of Thailand, where was characterized as clay soil.

\subsection{Deoiled Jatropha seedcake}

The deoiled Jatropha seedcake was generously provided by the Namman saboodum Thai Limited Company. The seedcake was reserved at room temperature for three months prior to the usage as fertilizer.

\subsection{Plant materials and propagations}

Since all three vegetable crops do require difference agricultural practices. According to the recommendations by the Department of Agriculture, Thailand, the amount and ratio of chemical fertilizers, used for each crops, were 
varied among these crops. The plant growth and yield outcome from these three crops were independent of each other. However, the final purpose of this study is to trace the remnants of phorbol ester in leaf, fruit, and tuber vegetables as well as in the harvested soils. Thus, an ability to successfully cultivate each crop was the reason behind the different details of application of chemical fertilizer. Although the mixing of JSC at land preparation would aggravate the content of phorbol ester in the soil, such compound was hypothesized to decay at a harvest time (Joshi et al., 2011). Moreover, various rates of JSC would differently influence the growth and development of each crop. While propagation procedures were varied among these three crops, the three factors which remain the same sources for each treatment of propagations were chemical fertilizer, farm manure, and JSC.

\subsubsection{Chinese kale cv. Bang Bua Thong}

Field experiment was conducted during May to September 2008. Twenty four days seedlings were transplanted on June 14, 2008 to $5 \times 1.5 \mathrm{~m}$. plot size for 6 rows with row by plant spacing of $25 \times 20 \mathrm{~cm}$. Harvest area was 4 $\mathrm{m}^{2}$ of middle 4 rows. The experimental design was randomize completed block with 3 replications of 12 treatments. Thus, the whole trial consisted of 36 experimental units. Twelve treatments are as followed:

Treatment 1. Control (no JSC application).

2. Chemical fertilizer (as recommended by the Department of Agriculture).

Basal of $15-15-15$ rate $312.50 \mathrm{~kg} / \mathrm{ha}$ at land preparation

Top dress of $46-0-0$ rate $156.25 \mathrm{~kg} / \mathrm{ha}$ at 15 days after transplanted.

3. Farm manure as basal rate $9.4 \mathrm{t} / \mathrm{ha}$. at land preparation.

4. Jatropha seedcake (low rate) $2.5 \mathrm{t} / \mathrm{ha}$ as basal.

5. Jatropha seedcake (medium rate) $5.0 \quad \mathrm{t} / \mathrm{ha}$ as basal.

6. Jatropha seedcake (high rate) $10 \mathrm{t} / \mathrm{ha}$ as basal.

7. Chemical fertilizer half rate of recommended (Basal of $15-15-15$ rate $156.25 \mathrm{~kg} /$ ha and top dress of $46-0-0$ rate $78.125 \mathrm{~kg} / \mathrm{ha}$ ) + JSC low rate $2.5 \mathrm{t} / \mathrm{ha}$ as basal.

8. Chemical fertilizer half rate (same as treatment 7.) + JSC medium rate 5.0 t/ha

9. Chemical fertilizer half rate (same as treatment 7.) + JSC high rate $10 \mathrm{t} / \mathrm{ha}$.

10. Farm manure half rate $4.7 \mathrm{t} / \mathrm{ha}+\mathrm{JSC}$ low rate $2.5 \mathrm{t} / \mathrm{ha}$, both as basal.

11. Farm manure half rate $4.7 \mathrm{t} / \mathrm{ha}+\mathrm{JSC}$ medium rate $5.0 \mathrm{t} / \mathrm{ha}$, both as basal.

12. Farm manure half rate $4.7 \mathrm{t} / \mathrm{ha}+\mathrm{JSC}$ high rate $10 \mathrm{t} / \mathrm{ha}$, both as basal.

\subsubsection{Tomato var. Sida Tip}

Tomato var. Sida Tip seed was germinated on May 26, 2008. One month old seedling was transplanted into experimental field plot. Each experimental unit size was $3 \times 5 \mathrm{~m}^{2}$. Tomato seedlings were planted in $50 \times 75 \mathrm{~cm}$. to get 10 plants per row. Thus, there were 4 rows and 2 middle rows were harvested area. The experimental design was randomize completed block with 3 replications of 12 treatments which are as followed;

Treatment 1. Control (no JSC application)

2. Chemical fertilizer (as recommended by the Department of Agriculture)

Basal of $15-15-15$ rate $312.50 \mathrm{~kg} / \mathrm{ha}$ at land preparation

First top dress of $46-0-0$, rate $156.25 \mathrm{~kg} / \mathrm{ha}$ at 15 days after transplanted

Second to fourth top dress of $15-15-15$, rate $312.50 \mathrm{~kg} / \mathrm{ha}$ was divided into 3 parts, applied at 30,45 and 60 days after transplanted.

3. Farm manure as basal rate $9.4 \mathrm{t} / \mathrm{ha}$ at land preparation.

4. Jatropha seedcake (low rate) $2.5 \mathrm{t} / \mathrm{ha}$ as basal at land preparation.

5. Jatropha seedcake (medium rate) $5.0 \mathrm{t} / \mathrm{ha}$ as basal at land preparation

6. Jatropha seedcake (high rate) $10 \mathrm{t} / \mathrm{ha}$ as basal at land preparation.

7. Chemical fertilizer half rate of recommended basal of $15-15-15$ rate $156.25 \mathrm{~kg} / \mathrm{ha}+$

JSC low rate $2.5 \mathrm{t} / \mathrm{ha}$ at land preparation. And top dress application as half of that in treatment 2.

8. Chemical fertilizer half rate of recommended basal of $15-15-15$ rate $156.25 \mathrm{~kg} / \mathrm{ha}+$ 
JSC medium rate $5.0 \mathrm{t} / \mathrm{ha}$ at land preparation. And top dress application as half of that in treatment 2 .

9. Chemical fertilizer half rate of recommended basal $15-15-15$ rate $156.25 \mathrm{~kg} / \mathrm{ha}+$ JSC high rate $10 \mathrm{t} / \mathrm{ha}$ at land preparation. And top dress application as half of that in treatment 2.

10. Farm manure half rate of recommended basal $4.7 \mathrm{t} / \mathrm{ha}+\mathrm{JSC}$ low rate $2.5 \mathrm{t} / \mathrm{ha}$ at land preparation

11. Farm manure half rate of recommended basal $4.7 \mathrm{t} / \mathrm{ha}+\mathrm{JSC}$ medium rate $5.0 \mathrm{t} / \mathrm{ha}$ at land preparation.

12. Farm manure half rate of recommended basal $4.7 \mathrm{t} / \mathrm{ha}+\mathrm{JSC}$ high rate $10 \mathrm{t} / \mathrm{ha}$ at land preparation.

\subsubsection{Sweet potato var. Muan Tor Puak}

Field experiment was conducted during December 2008 to March 2009. Two months old sweet potato top vine of $50 \mathrm{~cm}$ length were planted with row by hill spacing of $75 \times 30 \mathrm{~cm}$ for 4 rows. Harvest area was two middle rows of $6 \mathrm{~m}^{2}$. The experimental design was randomize completed block with 3 replications of 15 treatments. Thus, there were 45 subplots altogether. Since the propagation scheme for this, sweet potato, was the last experiment, we added the additional of three treatments to it. Twelve treatments are as the following;

Treatment 1. Control (no JSC application).

2. Chemical fertilizer (as recommended by the Department of Agriculture).

Basal of $13-13-21$ at the rate $250 \mathrm{~kg} / \mathrm{ha}$ at land preparation

Topdress of $13-13-21$, at the rate $250 \mathrm{~kg} / \mathrm{ha}$ at 45 days after planting

3. Farm manure as basal at the rate $9.4 \mathrm{t} / \mathrm{ha}$ at land preparation.

4. Jatropha seedcake (low rate) $2.5 \mathrm{t} / \mathrm{ha}$ as basal at land preparation.

5. Jatropha seedcake (medium rate) 5.0 t/ha as basal at land preparation

6. Jatropha seedcake (high rate) $10 \mathrm{t} / \mathrm{ha}$ as basal at land preparation.

7. Chemical fertilizer half rate of recommended (basal of 13-13-21 at the rate $125 \mathrm{~kg} / \mathrm{ha}$ and another 125 at 45 days after planting) + JSC low rate $2.5 \mathrm{t} / \mathrm{ha}$ as basal.

8. Chemical fertilizer half rate of recommended + JSC medium rate, 5.0 t/ha.

9. Chemical fertilizer half rate of recommended + JSC high rate, $10 \mathrm{t} / \mathrm{ha}$.

10. Farm manure half rate $4.7 \mathrm{t} / \mathrm{ha}+\mathrm{JSC}$ low rate $2.5 \mathrm{t} / \mathrm{ha}$, both as basal.

11. Farm manure half rate $4.7 \mathrm{t} / \mathrm{ha}+\mathrm{JSC}$ medium rate $5.0 \mathrm{t} / \mathrm{ha}$, both as basal.

12. Farm manure half rate $4.7 \mathrm{t} / \mathrm{ha}+\mathrm{JSC}$ high rate $10 \mathrm{t} / \mathrm{ha}$, both as basal.

\subsection{Harvesting schedule}

\subsubsection{Chinese kale cv. Bang Bua Thong}

After transplanted for 25 days, the green leafy vegetables were harvested. So a total of 49 days old plants were harvested.

\subsubsection{Tomato var. Sida Tip}

The harvest schedules of tomato were divided into three times. The tomato was harvested after 106 (green fruit stage), 120 (ripen stage), and 136 (mature stage) days after the germination day.

2.4.3 Sweet potato var. Muan Tor Puak

90 days old sweet potato was harvested for tuber yield.

\subsection{Nutrient analysis and physico-chemistry property determination of soil}

All the pulverized samples from Chinese kale, tomato, and sweet potato were subjected to the dehydration machine, after that 100 grams of each vegetable powder were collected for the plant analysis. Nitrogen content in these edible plant parts was determined using the semi-micro-kjeldahl method. Phosphorous and Potassium contents were specified by Vanado molybdophosphoric acid yellow method and atomic absorption 
spectrophotometer, respectively. The $\mathrm{pH}$ was determined with $\mathrm{pH}$ meter (Cyberscan, EUTECH $\mathrm{pH} 510$ ) on 1:2.5 $(\mathrm{w} / \mathrm{v})$ soil/distilled water. The organic matter of soil was analyzed by the wet oxidation method (Walkley and Black).Triplicate determinations were performed.

\subsection{Phorbol ester residue analysis}

The analyses were done following the method of Nokkaew and Punsuvon, 2009. In brief, $10 \mathrm{~g}$ of dry JSC, dry edible vegetable parts (Chinese kale leaf, tomato fruit, sweet potato tuber), and dry soil were extracted with 250 $\mathrm{ml} \mathrm{CH}_{3} \mathrm{OH}$ in soxhlet extractor for 4 hours. Then the extract solvent was further evaporated by vacuum rota evaporator until $10 \mathrm{ml}$ of solution was obtained. One portion of solution was analyzed for the concentration of phorbol ester by HPLC-UV with TPA as external standard. Another portion of solution was further evaporated to $1 \mathrm{ml}$ of solution. The solution was confirmed by LC-MS/MS with multiple reactions monitoring (MRM) mode. The mode was set up for using the ionization of parent ion with molecular mass of 711 to daughter ion with molecular mass of 311 and 293.

\section{Results and discussions}

\subsection{Plant growth and yield}

\subsubsection{Chinese kale}

To measure the growth of Chinese kale, five parameters were subjected to be analyzed, namely leaf length, leaf width, plant height, canopy height, and canopy width. The trends towards these five characters were similar within each treatment as shown in Table 1. Among all twelve treatments, the one with chemical fertilizer provided the best outcome as an appearance of the largest of the plant growth characters. Chemical fertilizer was rich in Nitrogen in an anticipation of promoting the growth and development of leaf. The second best treatments were half rate of recommended chemical fertilizer added with JSC at high rate $(1 / 2 \mathrm{CF}+\mathrm{JSC}(\mathrm{H}))$ and low rate $(1 / 2$ $\mathrm{CF}+\mathrm{JSC}(\mathrm{L}))$. The treatments of half rate of farm manure and the additional of JSC at medium, high, and low rate $(1 / 2 \mathrm{FM}+\mathrm{JSC}(\mathrm{M}), 1 / 2 \mathrm{FM}+\mathrm{JSC}(\mathrm{H})$, and $1 / 2 \mathrm{FM}+\mathrm{JSC}(\mathrm{L}))$ resulted in a medium-sized growth of Chinese kale. This middling growth also evidenced in the treatment with high rate of JSC (JSC(high)). However, the rest of the treatments exemplified the growths of Chinese kale that were comparable to the control.

The total yields were collected from the total fresh weight of harvested Chinese kale from each treatment. The highest yield (9.87 and $9.08 \mathrm{t} / \mathrm{ha}$ ) were obtained from the treatments of chemical fertilizer and $1 / 2$ chemical fertilizer plus the high rate of JSC (Chem.Fert and $1 / 2 \mathrm{CF}+\mathrm{JSC}(\mathrm{H})$ ). Therefore, it could be implied that the treatment with JSC would be able to partly replace the usage of chemical fertilizer. Application of JSC has the potential to be a practical organic fertilizer for growing Chinese kale. Moreover, the next highest yield belonged to the treatment of half rate of chemical fertilizer plus the low rate of JSC $(1 / 2 \mathrm{CF}+\mathrm{JSC}(\mathrm{L}))$ at $7.07 \mathrm{t} / \mathrm{ha}$. The usage of JSC as fertilizer could, therefore, alleviated the problem of high price of chemical fertilizer. The other treatments reflected somewhat low performance of the total yield. Among these treatments, the farm manure application gave the poor yield of Chinese kale. The marketable yield was derived from the total yield as some old leaves of Chinese kale were picked off. These two types of yield were, nevertheless, representing an identical trend.

\subsubsection{Tomato}

Total fruit yield and yield components of the harvested tomato as a result of the twelve different treatments were presented in table 2. The highest tomato fruit yield was obtained from the set of application with half rate of chemical fertilizer and JSC at every rate. All high, medium, and low rate treatments $(1 / 2 \mathrm{CF}+\mathrm{JSC}(\mathrm{H}), 1 / 2$ $\mathrm{CF}+\mathrm{JSC}(\mathrm{M})$, and $1 / 2 \mathrm{CF}+\mathrm{JSC}(\mathrm{L}))$ were able to give a yield of $8.85,8.41$, and $7.40 \mathrm{t} / \mathrm{ha}$, respectively.

Interestingly, the application of only JSC at a high rate (JSC(high)) to the fruit yield of tomato was comparable to the treatment with chemical fertilizer (Chem.Fert) as can be seen by the number of 6.90 and $6.65 \mathrm{t} / \mathrm{ha}$. Thus providing JSC to the tomato farm site could be resulted in an increase of tomato fruit yield. The set of application of half rate of farm manure and JSC at all rates ( $1 / 2 \mathrm{FM}+\mathrm{JSC}(\mathrm{H}), 1 / 2 \mathrm{FM}+\mathrm{JSC}(\mathrm{M})$, and $1 / 2 \mathrm{FM}+\mathrm{JSC}(\mathrm{L}))$ gave the medium yield at $6.19,5.70$, and $5.09 \mathrm{t} /$ ha, respectively. However, the treatment with full rate of farm manure and medium rate of JSC showed even lower amount of fruit yield, at 4.71 and $4.26 \mathrm{t} / \mathrm{ha}$. The control treatment led to the only amount of yield of $3.86 \mathrm{t} / \mathrm{ha}$. Nevertheless, the application of JSC at the low rate resulted in the lowest yield of tomato at $3.50 \mathrm{t} / \mathrm{ha}$.

The yield components of tomato were measured with ten fruit weight, fresh thickness and total soluble sugar. Among these yield components, however, no significant differences were achieved from all twelve various treatments. 


\subsubsection{Sweet potato}

The growth of aerial parts in terms of canopy width and vine length, and the tuber yield were measured, as illustrated in table 3 . The highest growth of both canopy width and vine length were resulted in the treatments with high rate of JSC, ranging from a mix with chemical fertilizer, with farm manure, and by itself $(1 / 2$ $\mathrm{CF}+\mathrm{JSC}(\mathrm{H}), 1 / 2 \mathrm{FM}+\mathrm{JSC}(\mathrm{H})$, and JSC (high)).

Moreover, differences trends towards the plant growth and the tuber yield were seen. Although the tuber yield data did require the statistical analysis, interesting data could still be derived. The acquired highest figure of the tuber yield was not the same as that of the sweet potato growth. The treatment with only low rate of Jatropha seedcake (JSC(low)) could yield up to $9.09 \mathrm{t} / \mathrm{ha}$. The lower tuber yield of 7.93 and $7.81 \mathrm{t} / \mathrm{ha}$ were attained from the mixing with chemical fertilizer and farm manure $(1 / 2 \mathrm{CF}+\mathrm{JSC}(\mathrm{M})$ and $1 / 2 \mathrm{FM}+\mathrm{JSC}(\mathrm{M}))$, respectively. To a lesser extent, the treatment of full rate chemical fertilizer yielded $7.37 \mathrm{t} / \mathrm{ha}$. The least tuber yield of $4.31 \mathrm{t} / \mathrm{ha}$ and $4.20 \mathrm{t} / \mathrm{ha}$ were the outcome of control and farm manure treatments, respectively. However, the highest amount of tuber yield from the treatment with low rate (only $2.5 \mathrm{t} / \mathrm{ha}$ ) of JSC indicated that this economical treatment was suitable for a lessening of sweet potato production cost.

\subsection{Nutrient analysis}

\subsubsection{Chinese kale}

The percentages of plant nutrient, namely Nitrogen $(\mathrm{N})$, Phosphorous $(\mathrm{P})$, and Potassium $(\mathrm{K})$, in the leaf of Chinese kale were measured as shown in table 4 . The highest percentage of $\mathrm{N}$ was represented by the treatment of half rate farm manure mixed with high rate of JSC $(1 / 2 \mathrm{FM}+\mathrm{JSC}(\mathrm{H}))$. When this rate of JSC was reduced to medium ( $1 / 2 \mathrm{FM}+\mathrm{JSC}(\mathrm{M}))$, the percentage of $\mathrm{P}$ was found to be the highest. In addition, the substitution to half rate of chemical fertilizer $((1 / 2 \mathrm{CF}+\mathrm{JSC}(\mathrm{H}))$ provided the highest percentage of $\mathrm{K}$. When taking the lowest percentages of total N, P, and $\mathrm{K}$ into consideration, the treatment with low rate of JSC and half rate of chemical fertilizer mixed with medium rate of JSC (JSC(low) and $1 / 2 \mathrm{CF}+\mathrm{JSC}(\mathrm{M})$ ) often yielded in the lowest percentage of them. These treatments resulted in the percentages of nutrients that were even lower than the control treatment.

\subsubsection{Tomato}

Table 5. represented the tomato fruit analysis as the percentage of N, P, and $\mathrm{K}$ which were the result from each twelve different application. Among all treatments in every nutrient analysis, none of them showed any noticeable maximum percentage. This implied that the tomato fruit qualities from these twelve various treatments were relatively even.

\subsubsection{Sweet potato}

Sweet potato tuber analyses for percentage of N, P, and K were examined, as can be seen in Table 6 . These studies were aimed to test the effects of each treatment to the nutrients in a tuber. The striking percentage of $\mathrm{N}$ was obtained from the mixture of half rate chemical fertilizer and high rate of JSC $(1 / 2 \mathrm{CF}+\mathrm{JSC}(\mathrm{H}))$. High rate of Jatropha seedcake either mixed with half rate of farm manure $(1 / 2 \mathrm{FM}+\mathrm{JSC}(\mathrm{H}))$ or by itself (JSC(high)) were classified by the percentage of $\mathrm{N}$ as the second and third ranks. Interestingly, within all applications, the treatment with high rate $(10 \mathrm{t} / \mathrm{ha}$ ) of JSC (either applied alone or in combination with others) were proven to cause the higher percentage of $\mathrm{N}$ than the treatment with medium or low rates of JSC.

When the percentage of $\mathrm{P}$ was taken into account, all the treatments were leading to the greater percents than the control. Although the percentage of $\mathrm{K}$ from all twelve treatments was quite comparable, the treatments with high rate of JSC were causing the slightly higher of $\mathrm{K}$ percents than the other rates. The application with higher concentration of JSC did accordingly increase the amount of N and K percents in the sweet potato tuber. As N was essential in amino acid synthesis, the sweet potato tubers from treatments with increasing concentration of JSC were, therefore, containing a rising of protein contents. Consequently, these tubers also consisted of the higher content of carbohydrate, because the protein and carbohydrate synthesis necessitated the occurrence of K.

\subsection{Soil analysis}

\subsubsection{Chinese kale}

The soil analysis for $\mathrm{pH}$, organic matter, content of $\mathrm{P}$ and $\mathrm{K}$ from pre-planting and postharvest of Chinese kale by twelve various treatments were shown in table 7. After the propagation of vegetable, $\mathrm{pH}$ in the soil was rose up. The percentages of organic matter in all four treatments with farm manure (both applied alone and in a combination with JSC) were higher than in the pre-planting soil. The availabilities of $\mathrm{P}$ and $\mathrm{K}$ in the soil from 
postharvest of Chinese kale were found to be greater than that of pre-planting. While the values of both $\mathrm{P}$ and $\mathrm{K}$ in almost all treatments were relatively comparable to the control treatment, those of low rate of JSC (JSC(low)) was most fluctuated from the control.

\subsubsection{Tomato}

From the table 8., the $\mathrm{pH}$ of the soil from all the treatments were higher than that of the pre-planting. Interestingly, the highest value of $\mathrm{pH}$ was seen in the control treatment. It could be implied that the treatments with different types of fertilizers were somewhat affected the soil that used in growing tomato. However, this kind of cultivation might have absorbed the accessibility of organic matter in the soil, as all twelve treatments gave the decreased values in comparison to that of pre-planting soil. Although the comparison of availabilities of $\mathrm{P}$ and $\mathrm{K}$ between the postharvest and pre-planting soil showed an increasing value, the value among all fertilizers treatments and control treatment appeared relatively similar. Strikingly, all applications with high rate (10 t/ha) of JSC resulted in the greater availability of $\mathrm{P}$ and $\mathrm{K}$ than those of low and medium rates. The treatments with JSC, therefore, elevated the $\mathrm{K}$ fertility in the soil after growing tomato. This implied an effective utilization of JSC because K fertilizer could be used to increase tomato yield (Zhao-Hui et al., 2008). Moreover, Zhao-Hui and colleagues also reported that the moderate amount of $\mathrm{K}$ fertilizer had associated with the increasing in concentration of soluble sugar.

\subsubsection{Sweet potato}

Table 9. showed four values of soil analysis, in order to study any possible relations of each different treatment before and after growing tuber crop. The $\mathrm{pH}$ analysis between the pre-planting and postharvest soil sampling did not indicate any obvious differences. Neither did the percentage of the organic matter. Although there was more availability of $\mathrm{P}$ and $\mathrm{K}$ in postharvest than pre-planting soil sampling, relatively comparable data were obtained among all twelve different treatments.

\subsection{Phorbol ester residue analysis}

In this analytical experiment, the purpose was to determine the trace amount of phorbol ester in the Chinese kale leaves, tomato fruit and sweet potato tuber. Since phorbol ester was considered as a toxic constituent in the JSC. The study for a possibility of utilization of this seedcake as the organic fertilizer would, therefore, require an inspection for amounts of phorbol ester. The residue in the harvested soil was also examined.

The analysis of phorbol ester was done with up to two methods. In brief, three replicates of each propagation treatment were quantitatively analyzed using the HPLC with UV detector. The highest concentration among three replicates was selected for further confirmation analysis using the LC-MS/MS with multiple reaction monitor (MRM) mode.

In the HPLC experiment, the quantification was done by 12-O-tetradecanoylphorbol-13-acetate (TPA) as external standard, which appeared between $8-12$ minutes. The extraction from Jatropha seedcake was, thus, analyzed prior to any application to Chinese kale and tomato. Concentration of phorbol ester in this seedcake was $0.3246 \mathrm{mg} / \mathrm{g}$ ( Figure1). Consequently, this same sample was confirmed by the LC-MS/MS wih MRM mode, in order to identify the presence of phorbol ester. There were two peaks, as the compound was ionized from molecular weight 711 to 293 and 311 at 2.45 and 2.46 minute, respectively ( Figure2).

\subsubsection{Chinese kale}

The extracts from Chinese kale leaves were analyzed by HPLC as seen by the value of phorbol ester (mg/g) in table 10. In comparison with the pre-treatment concentration of phorbol ester $(0.3246 \mathrm{mg} / \mathrm{g})$, it was clearly shown that the phorbol ester from the harvested Chinese kale leaves had decreased. The values were ranged between $0.058-0.168 \mathrm{mg} / \mathrm{g}$. These same set of samples were also confirmed by LC-MS/MS to analyze the presence of phorbol ester. None of any peaks were found at the time of above mentioned ionization, which implied an absence of phorbol ester residue in Chinese kale leaf ( Figure 3).

The amount of phorbol ester was examined in the soil after harvesting Chinese kale (Table 11.), the outcome were varied from $0.0086-0.026 \mathrm{mg} / \mathrm{g}$. Although the presence of two peaks, obtained from LC-MS/MS, indicated the possibility of phorbol ester, these ranges of concentrations, achieved by HPLC, were still under the threshold value. Since the nontoxic species of Jatropha curcas contained the phorbol ester of $0.11 \mathrm{mg} / \mathrm{g}$ (Saetae et al., 2011), the amount of phorbol ester confined in the soil after harvested Chinese kale, was considered as negligible one. Moreover, when the amount of phorbol ester (Table 10. and 11.) was taken into consideration, it was clearly seen that the concentrations in the soil were much lower than that of the leaf. 


\subsubsection{Tomato}

The harvests of tomato fruit were done in three different time points. Table 10. indicated the amount of phorbol ester residue obtained from the HPLC analysis in first, second, and third harvest. The range of value of phorbol ester, extracted from tomoto fruit, had been decreased from the first compared to the second and the third harvest. Interestingly, the detected concentrations of phorbol ester were continuously minimized, for nearly all the treatments. Such extracts from all three harvests were consequently analyzed by LC-MS/MS, however, there was no peaks occurred during the time of phorbol ester ionization ( Figure 4). It could be concluded from these experiments that the phorbol ester was not remained in the tomato fruit after all three harvests.

As shown in table 11., the HPLC analysis for concentrations of phorbol ester in the soil after the third harvest were employed. All chromatograms displayed peaks in between $8-12$ minutes. However, from the confirmation analysis via the LC-MS/MS, the outcome of phorbol ester ionization indicated that there was no phorbol ester residue in the soil from all treatments.

\subsubsection{Sweet potato}

The concentrations of phorbol ester in sweet potato tuber and in the propagated soil were measured, as could be seen in table 10. and 11., respectively. Among all twelve various treatments, the amounts of phorbol ester resided in the sweet potato tube were in a slightly different range to each others. Moreover, no peaks were detected at the time of phorbol ester ionization by the LC-MS/MS analysis (data not shown). This indicated that the sweet potato tuber did not contain phorbol ester residue. Neither did the soil after harvesting sweet potato.

The fact that there was no detection of phorbol ester in the soil agreed well with the previous report from Devappa et al., 2010. Their experiments were designed to show a rate of phorbol ester degradation in the soil. Therefore, our results were to ascertain that the biodegradation of phorbol ester in the soil had completely accomplished. This agreed well with the recent report that phorbol ester in JSC could be completely degraded, via the aid of Psedomonas aeruginosa PseA, within nine days (Joshi et al., 2011). In conclusion, none of phorbol ester residue was detected by the confirmation assay with LC-MS/MS of edible parts of vegetable crops, namely Chinese kale leaf, tomato fruit, and sweet potato tuber. These confirmed the safety of utilization of JSC as fertilizer for vegetable crops.

\section{Conclusions}

The utilization of deoiled Jatropha curcas seedcake was proven to have potential for being used as an organic fertilizer for vegetable crops. Different concentration of JSC gave the various results on the yield of each vegetable crop. Treatment with the half rate of chemical fertilizer mixed with high rate $(10 \mathrm{t} / \mathrm{ha})$ of JSC had proven to provide the best marketable yield of Chinese kale, in which such yield was comparable to that of full rate of chemical fertilizer. In addition, the half rate of chemical fertilizer combined with any rates of JSC (low, medium, and high) gave the most tomato fruit yield. When applied with low rate $(2.5 \mathrm{t} / \mathrm{ha})$ of JSC to the sweet potato plot, the outcome showed the highest tuber yield. For the plant nutrient analysis, shown by the percentage of N, P, and K, Chinese kale leaf that had been treated with a mixture between the half rate of farm manure and high rate of JSC exhibited the greatest value of each analysis. However, there were no differences in tomato fruit qualities among the twelve various treatments. For sweet potato tuber, the applications of high rate of JSC (apply alone and apply in mix with either half rate of chemical fertilizer or farm manure) gave higher percentage of $\mathrm{N}$. Finally, when subjected to analytical chemistry analysis for phorbol ester, none of its residue could be found in Chinese kale leaf, tomato fruit, and sweet potato tuber. Neither did the residue of phorbol ester in the soils after the harvest from each plot. These studies implied the safety of an application of JSC as fertilizer in leaf, fruit, and tuber vegetables.

\section{Acknowledgements}

The authors thankfully acknowledge the financial assistance received under the research project entitled effects of Jatropha curcas seed cake on growth, yield and residual toxin on Chinese cabbage, tomato and sweet potato, funded by the D1 Oils Plant Science (Thailand) Co., Ltd. The author also acknowledge the project on development of soil, fertilizer, and environment, Department of Soil Science, Faculty of Agriculture, Kasetsart university, for providing necessary lab facilities. The views or opinions expressed in this manuscript are those of the authors.

\section{References}

Achtena W.M.J., Verchot L., Frankenc Y.J., Mathijsd E., Singhe V.P., Aertsa R. \& Muys B. (2008). Jatropha bio-diesel production and use. Biomass and Bioenergy, 32: 1063- 1084. http://dx.doi.org/10.1016/j.biombioe.2008.03.003 
Al-Mohammadi F. and Al-Zu'bi Y. (2011). Soil Chemical Properties and Yield of Tomato as Influenced by Different Levels of Irrigation Water and Fertilizer. Journal of Agricultural Science and Technology, 13: 289-299.

Devappa R. K., Makkar H. P.S. \& Becker K. (2010). Biodegradation of Jatropha curcas phorbol esters in soil. Journal of the Science of Food and Agriculture, 90: 2090-2097. http://dx.doi.org/10.1002/jsfa.4056

Gubitz G.M., Mittelbach M. \& Trabi M. (1999). Exploitation of the tropical oil seed plant Jatropha curcas L. Bioresource Technology, 67: 73-82.

Goel G., Makkar H.P. S., Francis G. \& Becker K. (2007). Phorbol Esters: Structure, Biological Activity, and Toxicity in Animals. International Journal of Toxicology, 26: 279-288. http://dx.doi.org/10.1080/10915810701464641

Jain S. \& Sharma M.P. (2010). Prospects of biodiesel from Jatropha in India: A review. Renewable and Sustainable Energy Reviews, 14: 763-771. http://dx.doi.org/10.1016/j.rser.2009.10.005

Juan J.C., Kartika D.A., Wu T.Y. \& Hin T.Y.Y. (2011). Biodiesel production from jatropha oil by catalytic and non-catalytic approaches: An overview. Bioresource Technology, 102: $452-460$. http://dx.doi.org/10.1016/j.biortech.2010.09.093

Jouquet E. P., Bloquel E., Doan T. T., Ricoy M., Orange D., Rumpel C., \& Duc T. T. (2011) Do Compost and Vermicompost Improve Macronutrient Retention and Plant Growth in Degraded Tropical Soils? Compost Science \& Utilization, 19: 15-24.

Joshi C., Mathur P. \& Khare S. K. (2011). Degradation of phorbol esters by Pseudomonas aeruginosa PseA during solid-state fermentation of deoiled Jatropha curcas seed cake. Bioresource Technology, 102: 4815-4819.

Koh M.Y. \& Ghazi T. I.M. (2011). A review of biodiesel production from Jatropha curcas L. oil. Renewable and Sustainable Energy Reviews, 15: 2240-2251. http://dx.doi.org/ 10.1016/j.rser.2011.02.013

Kumar A. \& Sharma S. (2008). An evaluation of multipurpose oil seed crop for industrial uses (Jatropha curcas L.): A review. Industrial crops and products, 28: 1-10. http://dx.doi.org/ 10.1016/j.indcrop.2008.01.001

Nokkaew R. \& Punsuvon V. (2009). Analysis of phorbol esters residue in soil and vegetable with using jatropha curcus seed cake as fertilizer. Proceeding in $35^{\text {th }}$ Congress on Science and Technology of Thailand. 1-4.

Saetae D., Kleekayai T., Jayasena V. \& Suntornsuk W. (2011). Functional Properties of Protein Isolate Obtained from Physic Nut (Jatropha curcas L.) Seed Cake. Food Science and Biotechnology, 20: 29-37. http://dx.doi.org/10.1007/s10068-011-0005-x

Saetae D. \& Suntornsuk W. (2011). Toxic Compound, Anti-Nutritional Factors and Functional Properties of Protein Isolated from Detoxified Jatropha curcas Seed Cake. International Journal of Molecular Sciences, 12: 66-77. http://dx.doi.org/10.3390/ijms12010066

Sands D. C. , Morris C. E. , Dratz E. A. \& Pilgeram A. (2009). Elevating optimal human nutrition to a central goal of plant breeding and production of plant-based foods. Plant Science, 117: $377-389$. http://dx.doi.org/10.1016/j.plantsci.2009.07.011.

van Wyk J.P.H. (2001). Biotechnology and the utilization of biowaste as a resource for bioproduct development. Trends in Biotechnology, 19: 172-177.

Zhao-Hui L., Li-Hua J., Xiao-Lin L., Hardter R., Wen-Jun Z., Yu-Lan Z. \& Dong-Feng Z. (2008). Effect of N and K Fertilizers on Yield and Quality of Greenhouse Vegetable Crops. Pedoshere, 18: 496-502. 
Table 1. Average growth characters and fresh vegetable yield of chinese kale cv. Bang Bua Thong as the effects of different treatments

\begin{tabular}{|c|c|c|c|c|c|c|c|}
\hline & Leaf & Leaf & Plant & Canopy & Canopy & Total & Marketable \\
\hline Treatment & length & width & height & height & width & yield & yield \\
\hline & $(\mathrm{cm})$. & $(\mathrm{cm})$. & $(\mathrm{cm})$. & $(\mathrm{cm})$. & $(\mathrm{cm})$. & $(\mathrm{t} / \mathrm{ha})$ & $(\mathrm{t} / \mathrm{ha})$ \\
\hline Control & $10.87 \mathrm{c}$ & $8.70 \mathrm{~b}$ & $7.39 \mathrm{~b}$ & $19.83 \mathrm{c}$ & $13.27 \mathrm{~cd}$ & $4.12 \mathrm{c}$ & $3.75 \mathrm{c}$ \\
\hline Chem.Fert & $14.83 \mathrm{a}$ & $12.26 \mathrm{a}$ & $15.83 \mathrm{a}$ & $29.27 \mathrm{a}$ & $21.27 \mathrm{a}$ & $9.87 \mathrm{a}$ & $8.95 \mathrm{a}$ \\
\hline Farm manure & $11.18 \mathrm{c}$ & $8.58 \mathrm{~b}$ & $7.73 \mathrm{~b}$ & $20.47 \mathrm{c}$ & $17.00 \mathrm{bc}$ & $2.02 \mathrm{e}$ & $1.92 \mathrm{e}$ \\
\hline JSC(low) & $9.75 \mathrm{c}$ & $7.05 \mathrm{~b}$ & $7.26 \mathrm{~b}$ & $18.37 \mathrm{c}$ & $13.57 \mathrm{~cd}$ & $1.77 \mathrm{e}$ & $1.09 \mathrm{e}$ \\
\hline JSC(medium) & $9.63 \mathrm{c}$ & $7.04 \mathrm{~b}$ & $7.83 \mathrm{~b}$ & $17.60 \mathrm{c}$ & $12.33 \mathrm{~d}$ & $4.08 \mathrm{c}$ & $3.62 \mathrm{c}$ \\
\hline JSC(high) & $11.35 \mathrm{bc}$ & $9.63 \mathrm{ab}$ & $9.06 \mathrm{~b}$ & $22.91 \mathrm{bc}$ & $14.42 \mathrm{~cd}$ & $3.77 \mathrm{~cd}$ & $3.31 \mathrm{~cd}$ \\
\hline $1 / 2 \mathrm{CF}+\mathrm{JSC}(\mathrm{L})$ & $12.10 \mathrm{abc}$ & $10.03 \mathrm{ab}$ & $10.13 \mathrm{~b}$ & $20.90 \mathrm{c}$ & $14.23 \mathrm{~cd}$ & $7.07 \mathrm{~b}$ & $6.55 \mathrm{~b}$ \\
\hline $1 / 2 \mathrm{CF}+\mathrm{JSC}(\mathrm{M})$ & $9.76 \mathrm{c}$ & $8.00 \mathrm{~b}$ & $8.33 \mathrm{~b}$ & $19.07 \mathrm{c}$ & $12.60 \mathrm{~cd}$ & $4.55 \mathrm{c}$ & $3.98 \mathrm{c}$ \\
\hline $1 / 2 \mathrm{CF}+\mathrm{JSC}(\mathrm{H})$ & $14.23 \mathrm{ab}$ & $12.40 \mathrm{a}$ & $10.57 \mathrm{~b}$ & $27.87 \mathrm{ab}$ & $19.67 \mathrm{ab}$ & $9.08 \mathrm{a}$ & $7.93 \mathrm{a}$ \\
\hline $1 / 2 \mathrm{FM}+\mathrm{JSC}(\mathrm{L})$ & $10.43 \mathrm{ac}$ & $7.63 \mathrm{~b}$ & $8.05 \mathrm{~b}$ & $20.77 \mathrm{c}$ & $15.40 \mathrm{~cd}$ & $2.60 \mathrm{de}$ & $2.36 \mathrm{e}$ \\
\hline $1 / 2 \mathrm{FM}+\mathrm{JSC}(\mathrm{M})$ & $12.07 \mathrm{abc}$ & $8.267 \mathrm{~b}$ & $9.60 \mathrm{~b}$ & $23.27 \mathrm{bc}$ & $15.23 \mathrm{~cd}$ & $4.12 \mathrm{c}$ & $3.68 \mathrm{c}$ \\
\hline $1 / 2 \mathrm{FM}+\mathrm{JSC}(\mathrm{H})$ & $11.50 \mathrm{bc}$ & $9.16 \mathrm{~b}$ & $8.85 \mathrm{~b}$ & $23.30 \mathrm{bc}$ & $15.20 \mathrm{~cd}$ & $3.99 \mathrm{c}$ & $3.58 \mathrm{c}$ \\
\hline $\mathrm{F}-$ test & $*$ & $*$ & $*$ & $*$ & $*$ & $*$ & $*$ \\
\hline LSD.05 & 2.67 & 2.66 & 3.59 & 5.33 & 4.027 & 1.2 & 1.1 \\
\hline CV $(\%)$ & 13.72 & 17.33 & 22.97 & 15.45 & 14.30 & 14.91 & 15.22 \\
\hline
\end{tabular}

Table 2. Fruit yield and yield components of tomato var. Sida Tip as affected by different treatments

\begin{tabular}{|c|l|c|c|c|}
\hline \multirow{2}{*}{ Treatment } & Yield & 10-fruit wt. & Fresh thickness & Total soluble sugar \\
\cline { 2 - 5 } & $(\mathrm{t} / \mathrm{ha})$ & $(\mathrm{g})$ & $(\mathrm{mm})$ & $(\mathrm{brix})$ \\
\hline Control & $3.86 \mathrm{gh}$ & 239.00 & 4.70 & 10.13 \\
\hline Chem.Fert & $6.65 \mathrm{bcde}$ & 227.00 & 4.55 & 9.90 \\
\hline Farm manure & $4.71 \mathrm{efgh}$ & 259.00 & 4.39 & 8.60 \\
\hline JSC(low) & $3.50 \mathrm{~h}$ & 267.66 & 4.36 & 7.63 \\
\hline JSC(medium) & $4.26 \mathrm{fgh}$ & 249.33 & 4.38 & 10.00 \\
\hline JSC(high) & $6.90 \mathrm{bcd}$ & 232.66 & 4.48 & 8.96 \\
\hline $1 / 2 \mathrm{CF}+\mathrm{JSC}(\mathrm{L})$ & $7.40 \mathrm{abc}$ & 229.33 & 4.41 & 8.96 \\
\hline $1 / 2 \mathrm{CF}+\mathrm{JSC}(\mathrm{M})$ & $8.41 \mathrm{ab}$ & 229.00 & 4.23 & 10.16 \\
\hline $1 / 2 \mathrm{CF}+\mathrm{JSC}(\mathrm{H})$ & $8.85 \mathrm{a}$ & 222.66 & 4.47 & 8.81 \\
\hline $1 / 2 \mathrm{FM}+\mathrm{JSC}(\mathrm{L})$ & $5.09 \mathrm{defgh}$ & 239.33 & 4.45 & 9.06 \\
\hline $1 / 2 \mathrm{FM}+\mathrm{JSC}(\mathrm{M})$ & $5.70 \mathrm{cdefg}$ & 259.00 & 4.78 & 10.40 \\
\hline $1 / 2 \mathrm{FM}+\mathrm{JSC}(\mathrm{H})$ & $6.19 \mathrm{cdef}$ & 237.66 & 4.24 & 7.60 \\
\hline F-test & $*$ & $\mathrm{~ns}$ & $\mathrm{~ns}$ & $\mathrm{~ns}$ \\
\hline LSD.05 & 1.76 & - & - & - \\
\hline CV(./.) & 17.38 & 9.86 & 7.73 & 15.88 \\
\hline
\end{tabular}


Table 3. Growth and tuber yield of sweet potato as affected by different treatments

\begin{tabular}{|c|c|c|c|}
\hline \multirow{2}{*}{ Treatment } & Canopy width & Vine length & Tuber yield \\
\hline & $(\mathrm{cm})$ & $(\mathrm{cm})$ & $(\mathrm{t} / \mathrm{ha})$ \\
\hline Control & $36.33 \mathrm{e}$ & $91.46 \mathrm{de}$ & 4.31 \\
\hline Chem.Fert & $50.86 \quad$ cde & 110.33 bcde & 7.37 \\
\hline Farm manure & 42.06 & 92.26 & 4.20 \\
\hline JSC(low) & 55.06 & 106.53 bcde & 9.09 \\
\hline JSC(medium) & $56.33 \mathrm{~cd}$ & $125.46 \quad \mathrm{ab}$ & 6.41 \\
\hline JSC(high) & 68.33 abc & $133.06 \mathrm{ab}$ & 5.63 \\
\hline $1 / 2 \mathrm{CF}+\mathrm{JSC}(\mathrm{L})$ & 50.33 cde & 110.60 & 6.60 \\
\hline $1 / 2 \mathrm{CF}+\mathrm{JSC}(\mathrm{M})$ & 56.06 & $119.33 \mathrm{abcd}$ & 7.93 \\
\hline $1 / 2 \mathrm{CF}+\mathrm{JSC}(\mathrm{H})$ & 77.73 & 146.00 & 5.81 \\
\hline $1 / 2 \mathrm{FM}+\mathrm{JSC}(\mathrm{L})$ & $43.40 \mathrm{de}$ & $93.20 \mathrm{cde}$ & 5.81 \\
\hline $1 / 2$ FM+JSC(M) & $58.20 \quad$ bcd & $123.20 \quad a b c$ & 7.81 \\
\hline $1 / 2 \mathrm{FM}+\mathrm{JSC}(\mathrm{H})$ & $75.80 \quad \mathrm{ab}$ & $135.73 \mathrm{ab}$ & 6.56 \\
\hline F-test & $*$ & $*$ & ns \\
\hline LSD.05 & 19.38 & 30.73 & - \\
\hline CV(./.) & 15.97 & 12.16 & 39.87 \\
\hline
\end{tabular}

Table 4. Plant analysis of Chinese kale var. Bang Bua Thong for total N, P and K percentage as affected by different treatments

Note; method analysis:

\begin{tabular}{|c|c|c|c|}
\hline Treatment & $\mathrm{N}^{1 /}(\%)$ & $\mathbf{P}^{2 /}(\%)$ & $K^{3 /}(\%)$ \\
\hline Control & 2.30 & 0.56 & 3.06 \\
\hline Chem.Fert & 2.14 & 0.61 & 2.64 \\
\hline Farm manure & 2.27 & 0.63 & 2.62 \\
\hline JSC(low) & 1.92 & 0.54 & 2.97 \\
\hline JSC(medium) & 2.27 & 0.59 & 3.51 \\
\hline JSC(high) & 2.34 & 0.58 & 2.81 \\
\hline $1 / 2 \mathrm{CF}+\mathrm{JSC}(\mathrm{L})$ & 1.92 & 0.64 & 3.12 \\
\hline $1 / 2 \mathrm{CF}+\mathrm{JSC}(\mathrm{M})$ & 1.78 & 0.51 & 2.39 \\
\hline $1 / 2 \mathrm{CF}+\mathrm{JSC}(\mathrm{H})$ & 2.24 & 0.68 & 4.18 \\
\hline $1 / 2 \mathrm{FM}+\mathrm{JSC}(\mathrm{L})$ & 2.32 & 0.58 & 2.36 \\
\hline $1 / 2 \mathrm{FM}+\mathrm{JSC}(\mathrm{M})$ & 2.81 & 0.80 & 3.47 \\
\hline $1 / 2 \mathrm{FM}+\mathrm{JSC}(\mathrm{H})$ & 3.19 & 0.70 & 4.12 \\
\hline
\end{tabular}

1// Total N: Semi mocrokjeldehl method

2/ Total P: Vanado molybdophosphoric acid yellow method-

3/ Total K: Atomic absorption spectrophotometer

Table 5. Tomato fruit analysis for total percentage of $\mathrm{N}, \mathrm{P}$, and $\mathrm{K}$ percentage as affected by different treatments

\begin{tabular}{|c|c|c|c|}
\hline Treatment & $\mathrm{N}^{1 /}(\%)$ & $\mathrm{P}^{2 /}(\%)$ & $\mathrm{K}^{\frac{3}{3}}(\%)$ \\
\hline Control & 2.12 & 0.44 & 5.52 \\
\hline Chem.Fert & 2.48 & 0.41 & 5.67 \\
\hline Farm manure & 2.16 & 0.47 & 5.58 \\
\hline JSC(low) & 2.20 & 0.40 & 5.12 \\
\hline JSC(medium) & 2.11 & 0.75 & 5.29 \\
\hline JSC(high) & 2.18 & 0.45 & 5.38 \\
\hline $1 / 2$ CF+JSC(L) & 2.37 & 0.38 & 5.48 \\
\hline $1 / 2$ CF+JSC(M) & 2.30 & 0.42 & 5.42 \\
\hline $1 / 2$ CF+JSC(H) & 2.37 & 0.39 & 5.47 \\
\hline $1 / 2$ FM+JSC(L) & 2.06 & 0.48 & 5.69 \\
\hline $1 / 2$ FM+JSC(M) & 2.24 & 0.48 & 5.27 \\
\hline $1 / 2$ FM+JSC(H) & 2.12 & 0.44 & 5.45 \\
\hline
\end{tabular}

Note; method analysis:

1/ Total N: Semi mocrokjeldehl method

2/ Total P: Vanado molybdophosphoric acid yellow method

3/ Total K: Atomic absorption spectrophotometer 
Table 6. Plant analysis of sweet potato tuber for total N, P and K percentage as affected by different treatments

\begin{tabular}{|c|c|c|c|}
\hline Treatment & $\mathrm{N}^{1 /}(\%)$ & $\mathrm{P}^{2 /}(\%)$ & $\mathrm{K}^{3 /}(\%)$ \\
\hline Control & 0.71 & 0.21 & 1.18 \\
\hline Chem.Fert & 0.63 & 0.22 & 1.27 \\
\hline Farm manure & 0.69 & 0.22 & 1.10 \\
\hline JSC(low) & 0.61 & 0.22 & 1.14 \\
\hline JSC(medium) & 0.71 & 0.26 & 1.23 \\
\hline JSC(high) & 0.88 & 0.27 & 1.38 \\
\hline $1 / 2 \mathrm{CF}+\mathrm{JSC}(\mathrm{L})$ & 0.71 & 0.32 & 1.14 \\
\hline $1 / 2 \mathrm{CF}+\mathrm{JSC}(\mathrm{M})$ & 0.79 & 0.27 & 1.05 \\
\hline $1 / 2 \mathrm{CF}+\mathrm{JSC}(\mathrm{H})$ & 1.16 & 0.23 & 1.21 \\
\hline $1 / 2 \mathrm{FM}+\mathrm{JSC}(\mathrm{L})$ & 0.68 & 0.21 & 1.17 \\
\hline $1 / 2 \mathrm{FM}+\mathrm{JSC}(\mathrm{M})$ & 0.69 & 0.31 & 1.20 \\
\hline $1 / 2 \mathrm{FM}+\mathrm{JSC}(\mathrm{H})$ & 0.94 & 0.29 & 1.26 \\
\hline
\end{tabular}

Note; method analysis:

1// Total N: Semi mocrokjeldehl method

2/ Total P: Vanado molybdophosphoric acid yellow method-

3/ Total K: Atomic absorption spectrophotometer

Table 7. Soil analysis for $\mathrm{pH}$, organic matter, available $\mathrm{P}$ and $\mathrm{K}$ of preplanting and after Chinese kale harvested plots (postharvest) in different treatments

\begin{tabular}{|c|c|c|c|c|}
\hline Treatment & $\mathbf{p H}^{\mathbf{1}}$ & $\mathbf{O M}^{\mathbf{2}}(\%)$ & $\mathbf{P}^{\mathbf{3} /}(\mathrm{mg} / \mathrm{kg})$ & $\mathbf{K}^{\mathbf{4} /}(\mathrm{mg} / \mathrm{kg})$ \\
\hline Pre-planting & 7.0 & 2.61 & 49.04 & 271.69 \\
\hline Postharvest & & & & \\
\hline Control & 7.4 & 2.47 & 70 & 580 \\
\hline CF & 7.4 & 2.33 & 73 & 470 \\
\hline FM & 7.6 & 2.67 & 75 & 480 \\
\hline JSC(low) & 7.5 & 2.33 & 120 & 360 \\
\hline JSC(medium) & 7.4 & 2.63 & 87 & 570 \\
\hline JSC(high) & 7.3 & 2.33 & 79 & 450 \\
\hline $1 / 2$ CF+JSC(L) & 7.3 & 2.30 & 70 & 570 \\
\hline $1 / 2$ CF+JSC(M) & 7.4 & 2.33 & 68 & 500 \\
\hline $1 / 2$ CF+JSC(H) & 7.2 & 2.53 & 77 & 530 \\
\hline $1 / 2$ FM+JSC(L) & 7.5 & 2.67 & 80 & 560 \\
\hline $1 / 2$ FM+JSC(M) & 7.5 & 2.70 & 79 & 440 \\
\hline $1 / 2$ FM+JSC(H) & 7.4 & 2.80 & 85 & 580 \\
\hline
\end{tabular}

Note; method analysis:

1/ $\mathrm{pH}: \mathrm{pH}$ meter

2/ Organic Matter: Wet oxidation (Walkley and Black)

3/ Available P: Vanado molybdophosphoric acid yellow method

4/ Available K: Atomic absorption spectrophotometer 
Table 8. Soil analysis for $\mathrm{pH}$, organic matter and available $\mathrm{P}$ and $\mathrm{K}$ of soil sampling from preplanting and after tomato harvested plots (postharvest) in different treatments

\begin{tabular}{|c|c|c|c|c|}
\hline Treatment & $\mathbf{p H}^{\mathbf{1}}$ & $\mathbf{O M}^{2}(\%)$ & $\mathbf{P}^{\mathbf{3} /}(\mathrm{mg} / \mathrm{kg})$ & $\mathbf{K}^{\mathbf{4} /}(\mathrm{mg} / \mathrm{kg})$ \\
\hline Pre-planting & 6.8 & 2.65 & 50 & 270 \\
\hline Postharvest & & & & \\
\hline Control & 7.7 & 2.17 & 60 & 780 \\
\hline Chem.Fert & 6.7 & 2.40 & 61 & 980 \\
\hline Farm manure & 6.9 & 2.53 & 73 & 800 \\
\hline JSC(low) & 6.9 & 2.33 & 62 & 700 \\
\hline JSC(medium) & 7.2 & 2.13 & 64 & 640 \\
\hline JSC(high) & 7.0 & 2.30 & 65 & 1180 \\
\hline $1 / 2$ CF+JSC(L) & 7.0 & 2.23 & 70 & 840 \\
\hline $1 / 2$ CF+JSC(M) & 6.9 & 2.30 & 61 & 800 \\
\hline $1 / 2$ CF+JSC(H) & 6.9 & 2.40 & 72 & 980 \\
\hline $1 / 2$ FM+JSC(L) & 7.0 & 2.30 & 63 & 730 \\
\hline $1 / 2$ FM+JSC(M) & 7.2 & 2.33 & 65 & 830 \\
\hline $1 / 2$ FM+JSC(H) & 7.1 & 2.37 & 75 & 880 \\
\hline \multicolumn{5}{|r|}{}
\end{tabular}

-Note; method analysis:

1/ $\mathrm{pH}$ : $\mathrm{pH}$ meter

2/ Organic Matter: Wet oxidation (Walkley and Black)

3/ Available P: Vanado molybdophosphoric acid yellow method

4/ Available: Atomic absorption spectrophotometer

Table 9. Soil analysis for $\mathrm{pH}$, organic matter, available $\mathrm{P}$ and $\mathrm{K}$ of preplanting and after sweet potato harvested (post) plots $n$ different treatments

\begin{tabular}{|c|c|c|c|c|}
\hline Treatment & $\mathrm{pH}^{1 /}$ & $\mathrm{OM}^{2 /}(\%)$ & $\mathrm{P}^{3 /}(\mathrm{mg} / \mathrm{kg})$ & $\mathrm{K}^{4 /}(\mathrm{mg} / \mathrm{kg})$ \\
\hline Pre-planting & 6.8 & 2.1 & 37 & 197 \\
\hline Postharvest & & & & \\
\hline Control & 7.3 & 2.3 & 44 & 217 \\
\hline Chem.Fert & 7.1 & 2.2 & 38 & 293 \\
\hline Farm manure & 7.1 & 2.5 & 37 & 310 \\
\hline JSC(low) & 7.3 & 2.3 & 34 & 250 \\
\hline JSC(medium) & 7.2 & 2.5 & 46 & 300 \\
\hline JSC(high) & 7.0 & 2.7 & 39 & 280 \\
\hline $1 / 2$ CF+JSC(L) & 6.8 & 2.3 & 40 & 213 \\
\hline $1 / 2$ CF+JSC(M) & 6.8 & 2.4 & 36 & 210 \\
\hline $1 / 2$ CF+JSC(H) & 7.2 & 2.5 & 42 & 297 \\
\hline $1 / 2$ FM+JSC(L) & 7.1 & 2.4 & 44 & 197 \\
\hline $1 / 2$ FM+JSC(M) & 7.2 & 2.6 & 55 & 177 \\
\hline $1 / 2$ FM+JSC(H) & 7.1 & 2.6 & 44 & 187 \\
\hline
\end{tabular}

Note; method analysis:

${ }^{1 /} \mathrm{pH}: \mathrm{pH}$ meter

2/ Organic Matter: Wet oxidation (Walkley and Black)

3/ Available P: Vanado molybdophosphoric acid yellow method

4/ Available K: Atomic absorption spectrophotometer 
Table 10. Phorbol esters analysis (mg/g) via HPLC method of samples from Chinese kale, tomato, and sweet potato as the effects of different treatments

\begin{tabular}{|c|c|c|c|c|c|}
\hline \multirow{2}{*}{ Treatment } & \multirow{2}{*}{ Chinese Kale } & \multicolumn{3}{|c|}{ Tomato } & \multirow{2}{*}{ Sweet Potato } \\
\cline { 2 - 6 } & & $\mathbf{1}^{\text {st }}$ Harvest & $\mathbf{2}^{\text {nd }}$ Harvest & $\mathbf{3}^{\text {nd }}$ Harvest & \\
\hline & $\mathbf{( m g / g )}$ & $\mathbf{( m g / g )}$ & $\mathbf{( m g} / \mathbf{g})$ & $\mathbf{( m g} / \mathbf{g})$ & $\mathbf{( m g / g )}$ \\
\hline Control & 0.0812 & 0.3886 & 0.18 & 0.2258 & 0.1747 \\
\hline Chem. Fert & 0.0638 & 0.4212 & 0.2962 & 0.222 & 0.1505 \\
\hline Farm manure & 0.1253 & 0.4327 & 0.224 & 0.218 & 0.1938 \\
\hline JSC (low) & 0.0845 & 0.3653 & 0.1862 & 0.1944 & 0.1664 \\
\hline JSC (medium) & 0.0815 & 0.2594 & 0.2538 & 0.1488 & 0.0922 \\
\hline JSC (high) & 0.073 & 0.4082 & 0.2354 & 0.2253 & 0.1285 \\
\hline $1 / 2$ CF + JSC (L) & 0.168 & 0.3687 & 0.214 & 0.1608 & 0.1037 \\
\hline $1 / 2$ CF + JSC (M) & 0.058 & 0.3755 & 0.1733 & 0.2544 & 0.1733 \\
\hline $1 / 2$ CF + JSC (H) & 0.063 & 0.3728 & 0.3016 & 0.2067 & 0.1361 \\
\hline $1 / 2$ FM + JSC (L) & 0.0686 & 0.3773 & 0.229 & 0.2422 & 0.1407 \\
\hline $1 / 2$ FM + JSC (M) & 0.1161 & 0.2563 & 0.2692 & 0.2404 & 0.1389 \\
\hline $1 / 2$ FM + JSC (H) & 0.0951 & 0.2693 & 0.2817 & 0.1711 & 0.1267 \\
\hline
\end{tabular}

Table 11. Phorbol esters analysis $(\mathrm{mg} / \mathrm{g})$ via HPLC method of soil sampling from chinese kale, tomato, and sweet potato postharvested plots as the effects of different treatments

\begin{tabular}{|c|c|c|c|}
\hline \multirow{2}{*}{ Treatment } & Chinese Kale & Tomato after 3nd Harvest & Sweet Potato \\
\cline { 2 - 4 } & $\mathbf{( m g / g )}$ & $\mathbf{( m g / g )}$ & $\mathbf{( m g / g )}$ \\
\hline Control & 0.0206 & 0.033 & 0.0132 \\
\hline Chem. Fert & 0.0169 & 0.0293 & 0.0097 \\
\hline Farm manure & 0.0125 & 0.0313 & 0.0107 \\
\hline JSC (low) & 0.0153 & 0.0337 & 0.0111 \\
\hline JSC (medium) & 0.0173 & 0.0533 & 0.0116 \\
\hline SC (high) & 0.0157 & 0.0425 & 0.0204 \\
\hline $1 / 2$ CF + JSC (L) & 0.019 & 0.0306 & 0.0083 \\
\hline $1 / 2$ CF + JSC (M) & 0.0086 & 0.0413 & 0.0124 \\
\hline $1 / 2$ CF + JSC (H) & 0.0086 & 0.0407 & 0.0197 \\
\hline $1 / 2$ FM + JSC (L) & 0.0079 & 0.0278 & 0.0143 \\
\hline $1 / 2$ FM + JSC (M) & 0.0117 & 0.0325 & 0.0164 \\
\hline $1 / 2$ FM + JSC (H) & 0.019 & 0.0336 & 0.0132 \\
\hline
\end{tabular}




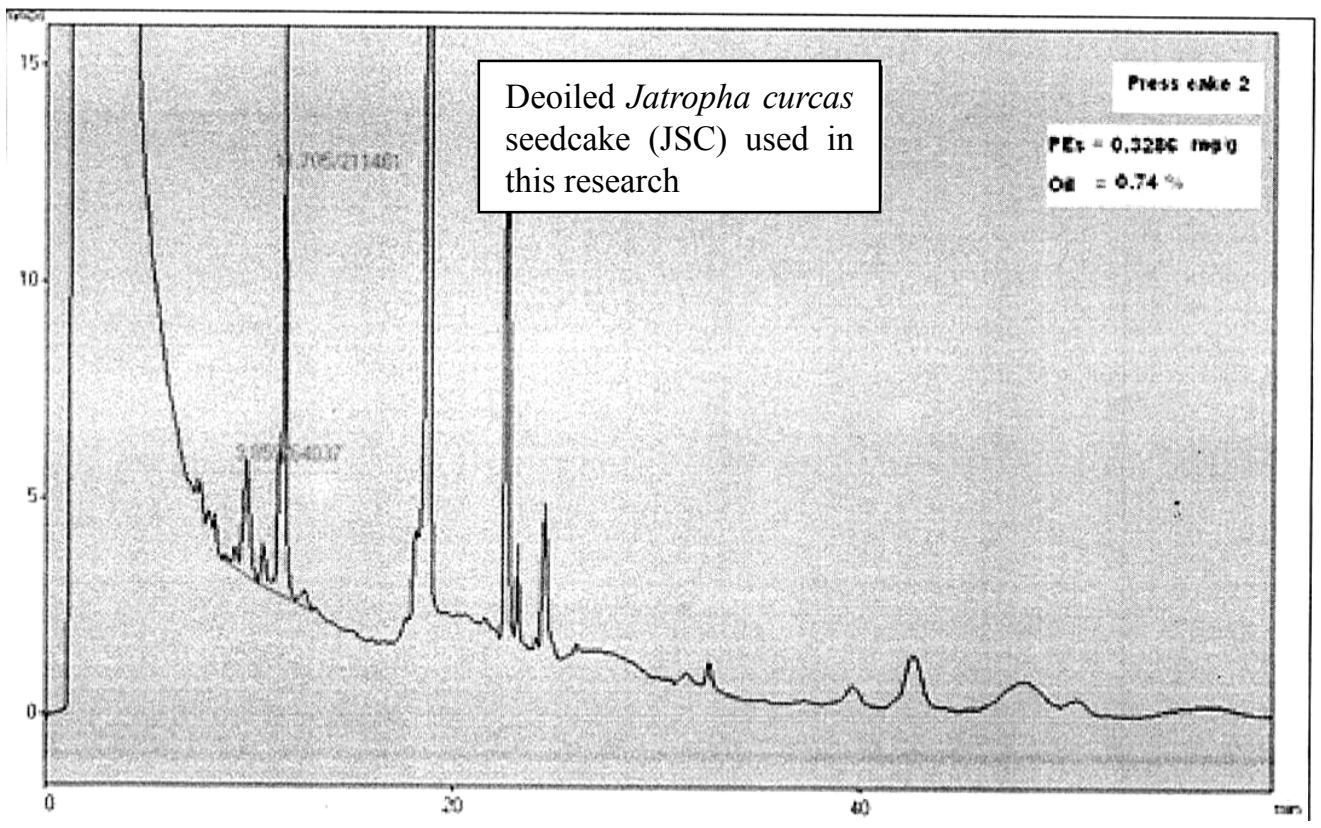

Figure 1. Chromatogram of phorbol ester obtained from HPLC analysis. These JSC were used in all the treatments for all vegetable crops

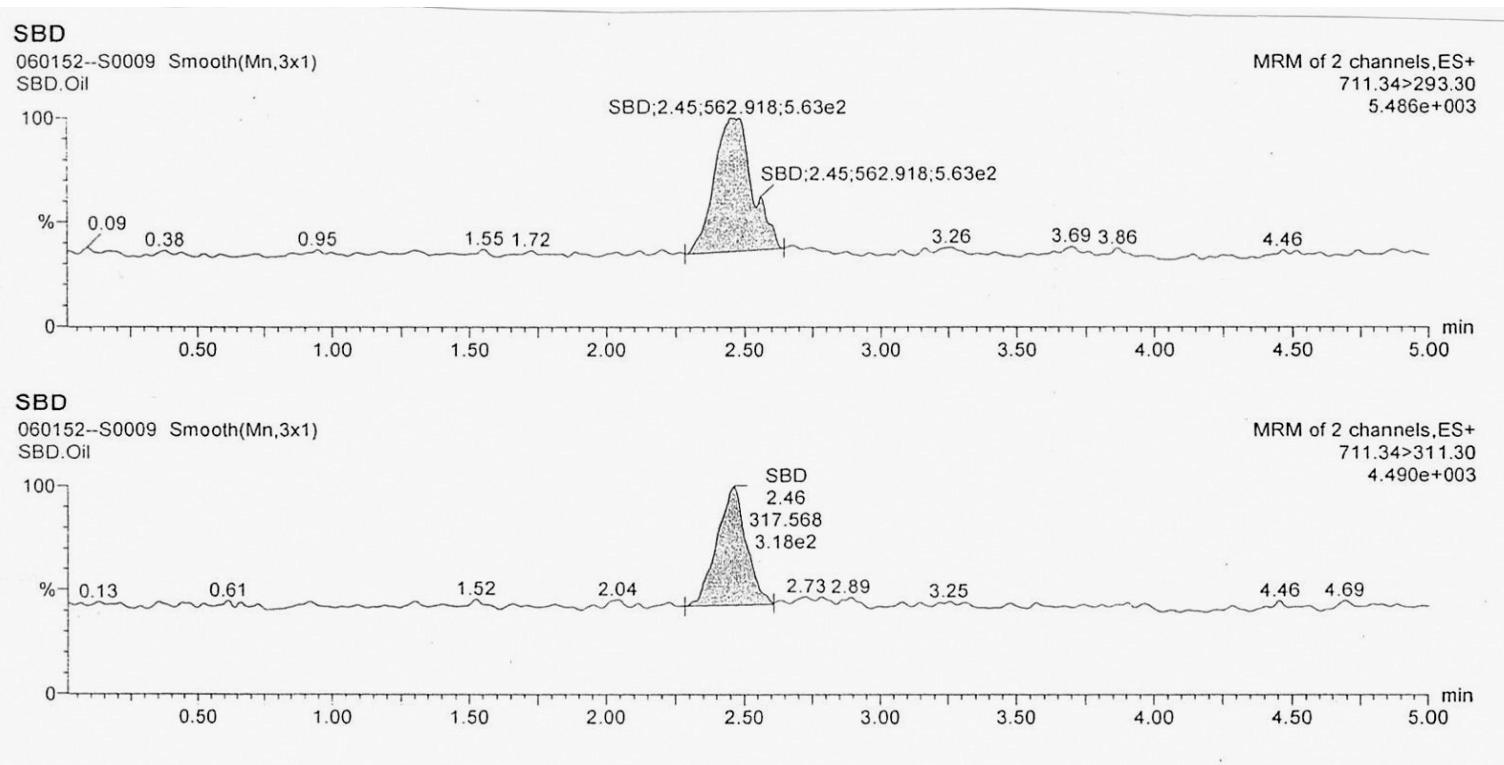

Figure 2. Chromatogram of phorbol ester obtained from the confirmation analysis via LC-MS/MS with MRM mode. Two peaks were presented 2.45 and 2.46 minutes. These JSC were used in all the treatments for all vegetable crops 


\section{SBD}

200152_S016 Smooth(Mn, 3x1)

Kana K106

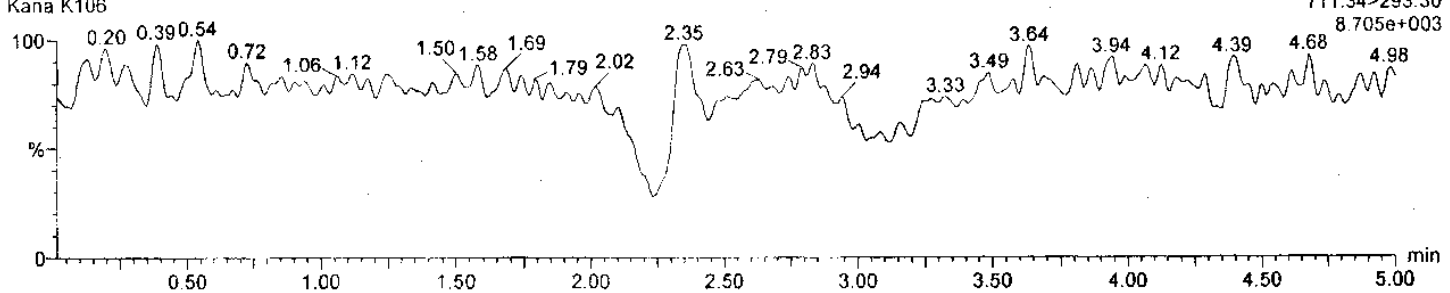

SBD

200152.\$016 Smooth(Mn.3×1)

Kana $K 106$

$100-$

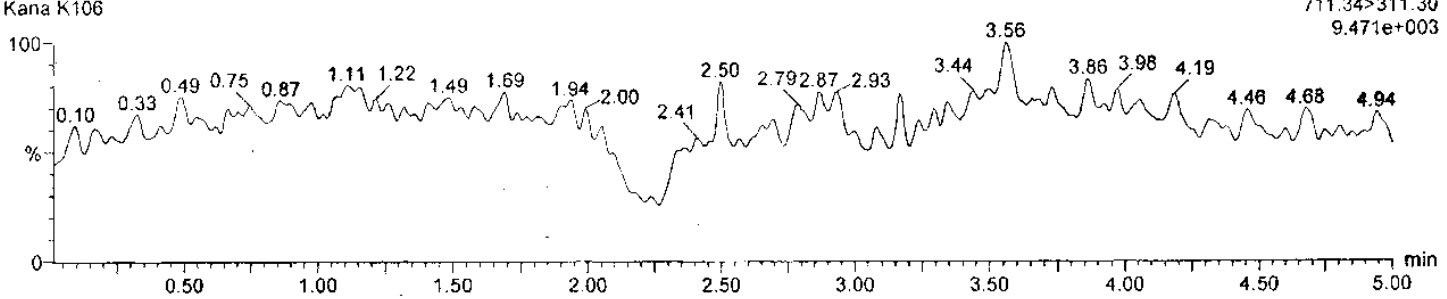

Figure 3. Chromatogram of phorbol ester from LC-MS/MS analysis of extract from Chinese kale leaf. None of any peaks occurred at 2.45 minute from both chromatograms, indicating that no phorbol ester residue

\section{SBD}

050152 S0010 Smooth $\{$ Mn, 3x1)

100

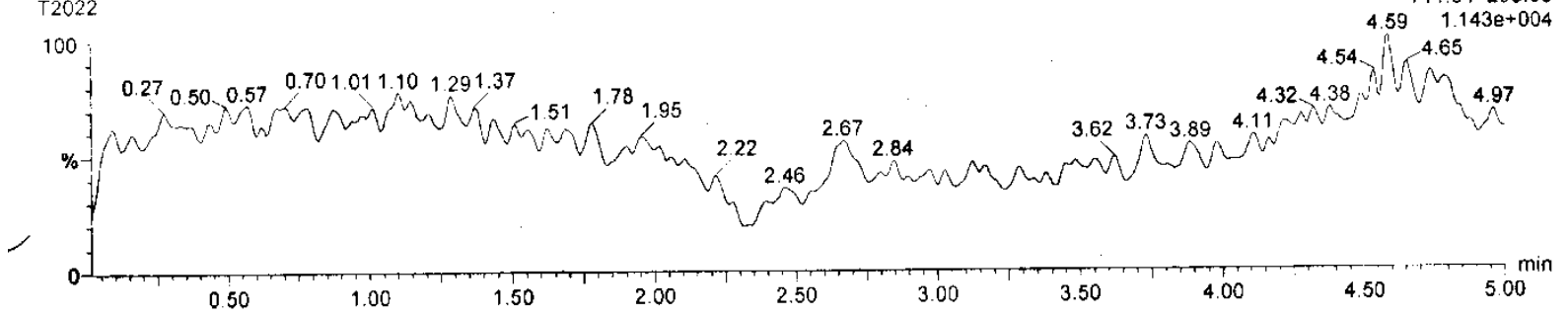

\section{SBD}

050152_S0010 Smooth(Mn,3xi)

T2022

1007

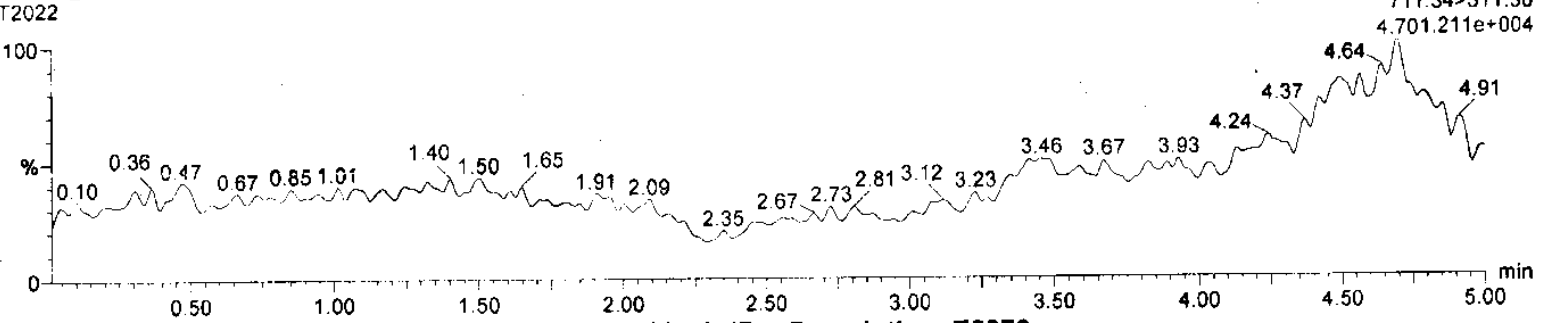

Figure 4. Chromatogram of phorbol ester from LC-MS/MS analysis of extract from tomato fruit. None of any peaks occurred at 2.45 minute from both chromatograms, indicating that no phorbol ester residue 